\title{
Comment
}

\section{Barry Hughes}

\begin{abstract}
$O$ arry White belongs to the school that advises governments 'don't just do something, sit there', for if things are done there is a high chance of a muck-up. However, he has made very heavy weather of restating familiar positions, partly because he wants to run three of them in the same short article, and they tend to get in the way of each other. The newest of the three is the theme of international business-cycle synchronisation. White sometimes comes close to saying that Australian activity (at least the cycles thereof) is determined exogenously by the OECD business cycle, so that there is very little independent macroeconomic policy action that we can take that would influence activity levels. But elsewhere he runs the textbook Mundell-Fleming argument from the 1960s (freshened up in the article with quotations from Sachs and Larrain) that in a regime of flexible exchange rates only monetary policy has activity potency, whereas fiscal policy is impotent through crowding-out effects. Finally, there are Milton Friedman's long and variable lags to guarantee that anything that might have been possible will be so mistimed as to generate perverse results.

I am not sure how White balances the activity implications of these three arguments, but presumably they lead to the conclusions that nothing much happens and that mistaken policy activism results in poorer current-account or inflation outcomes. The low inflation we now experience should pose something of a problem for his argument, but it is summarily dismissed as simply an unintended accident of an external era of quiescent inflation.
\end{abstract}

\section{Low Inflation: A Policy Success?}

Let us deal with inflation first. White states that the rapid fall in inflation to negligible levels was welcome; but this too was beyond the intentions of the government. Nonsense! Reducing inflation has been an important policy goal throughout the period of Labor government, with three major assaults to get the rate down to Reserve Bank Governor Bernie Fraser's current comfort ceiling of 3 per cent finally being greeted by success: wages policy in 1983-85; the events associated with the infamous 1988 'bringing home the bacon' Budget; and most recently, the events stemming from the Accord Mark VI. To say that recent disinflation was unintended makes one wonder where the author has been living over the past decade. 
The effectiveness or otherwise (as opposed to the intent) of anti-inflation policy needs to be argued, but White does no such thing. He scarcely mentions the subject before dismissing it from the reckoning, thus leaving his account of policy over the period totally unbalanced. To be sure, domestic unemployment has had a salutary effect. But what is important here is the improvement in relative performance. Not only has Australian inflation been reduced, but we have rejoined the club of low-inflation countries after an absence of two decades. White no doubt believes that the firefighting of 1986-87 (quarantining currency depreciation) and 1988-90 (the easy wicket of fast growth in domestic demand) had nothing to do with today's results; but for a variable (inflation) that is generally conceded to have a major component of inertia (hence the stress on various core rates), it is necessary to argue the irrelevance of past efforts, instead of assuming the inheritance to have been a gift from the gods. In the absence of any such argument, the results speak for themselves, spelling out a verdict quite inconvenient to White's general message.

\section{Fiscal Policy}

White's argument elsewhere suffers also from what Fritz Machlup used to call the 'fallacy of misplaced concreteness': the tendency to assume that real-world events can occur only in conformity with one's particular theory. His view of fiscal policy is entirely conditioned by the critical Mundell-Fleming assumption that interest-rate differentials dominate the course of exchange rates (thus leading to complete crowding out of the multiplier). As far as the Aussie commodity currency is concerned, this crucial assumption of the international textbooks is seriously under threat, with precious little evidence in its support. What the evidence does suggest is that the currency is much better described as an exogenous variable (determined by global commodity prices): in which case White's major fiscal policy argument is in trouble.

The arguments against using fiscal policy for fine tuning what have turned out normally over the decades to be short-lived business cycles are persuasive on other grounds (the long and variable lags, the difficulties of changing tax rates and transfer arrangements quickly, and the inability of public services to maintain a ready shelf of projects). Yet oddly enough those commentators who are most dismissive of such usage are often among the first to suggest budgetary fine tuning to attempt saving-investment reconciliation. The Keynesian case for fiscal policy remains sensible for non-normal business cycles, for which it was originally proposed (and even most sceptics refrain from calling for the actual budget to be balanced in a downturn). There is a reasonable argument that the early 1990s provided such a case, though the national accounts are much more eloquent about the inability of the public service to mount the policy spending planned than about the repercussions of the announced policy. There is, of course, a taxation and transfer side, and the record here needs examination. Perhaps because his (Mundell) theory tells him that fiscal policy will not work, White scarcely bothers to look, and where he does (for example, his attempted put down of the structural/cyclical distinction), any 
Keynesian would have no difficulty concluding that he had misunderstood the argument.

\section{Business-Cycle Synchronisation}

The extent of synchronisation of Australia's business cycle with that of the US or the OECD is a very fashionable topic, oddly enough at a time of the most desynchronised global business cycle in recent memory. Australian experience has resembled closely that of the US in the 1990s, but not that of the OECD (mainly because of the very different paths of Germany and Japan). Nevertheless, even a quick glance at the comparative GDP growth charts is very suggestive of international business-cycle links, whatever the transmission mechanisms. The most thorough local work on the topic is by Gruen and Shuetrim (1994), who indeed find strong correlations. Unlike White, they find next to no evidence that these links are driven by the terms of trade. Of more importance here, their work does not preclude an independent policy impact on domestic real activity. Indeed, they find evidence of such an impact from monetary policy, in the form of significant and important real cash interest-rate effects. Neither fiscal nor wages policy was modelled, any effects therefrom disappearing into the residuals of their equations. These latter account for over half the variance in the best-performing equations, so leaving reasonable scope for independent non-monetary policy effects, though to be fair to both Gruen \& Shuetrim and White the dependent variables (quarterly changes) are of a form likely to generate only limited explanatory power. Nevertheless, this evidence suggests that although world events hold considerable sway over our fortunes, we are not helpless.

\section{Recent Macroeconomic Policy: A Brief Preliminary Assessment}

Public policy (including the various Accords) had something to do with disinflation, which is to the good. The Hawke Government's expansionary fiscal policy in 198385 had some influence on the ensuing recovery (compare Europe under restrictive policy with both Australia and a US under Reagan pursuing a relabelled pumppriming), which helped at the time to avert a more serious problem of long-term unemployment and the inefficiencies that result. But, compared to the European alternative of heavy sedation, it left us more exposed to poor commodity prices.

The rest of the 1980s saw the economy bouncing off various walls (the international-debt binge at a time of financial deregulation, asset-price bubbles and stockmarket collapses, commodity-price roller coasters), which was a very difficult environment for any policy to confront. With the luxury of hindsight, we can see that public policy was too slow to stop an assets and goods demand boom getting out of hand, which proved to be a costly mistake. The subsequent reaction (in May 1988) started as early as that in other countries similarly affected, though clearly it could have been much stiffer in the early phases. Monetary policy was relied on, partly because fiscal policy was being used in combination with wages policy, partly because the political environment has virtually outlawed large tax increases, but mainly 
because monetary policy has always been the best way of controlling this sort of boom.

The second costly mistake was the usual one of keeping interest rates very high for too long, though in fairness to the policymakers most (but by no means all) outside commentators thought there would be a soft landing, and the phase of rate reductions was widely criticised as premature, wimpish and electorally inspired. This application of monetary policy could never fix current-account problems (indeed, as White complains, it would lead to a deterioration if the currency is sensitive to interest differentials - an important assumption). All it could have done, even if applied perfectly, was to take the heat out of the boom. But there was little chance of anything fixing the current account while the domestic demand boom raged. In any event, the economy ultimately stagnated. Prime Minister Paul Keating would no doubt be relieved that there is an argument that could let him off the hook.

When more time has elapsed (and firmer data become available) the consequences of Australian macroeconomic policy in the 1990 s will be subject to sensible debate. Recovery has been quite a bit stronger than many were arguing just a year ago, though inflation (to date at least) has been lower than general expectations of a similar vintage. While there are similarities with the US in both policy and outcomes (and some major differences), there are few with continental Europe or Japan.

Macroeconomic policy has a mixed record over the past decade, but human failure to achieve perfection is not a reasonable basis on which to award the beauty prize unseen to another contestant. Some argue, for example, that the licence given to greed in the 1980 s was a major cause of our problems, but it would be equally unreasonable to urge regulation simply on the basis of the flaws clearly evident over this period. Nor is it sensible to urge fixed exchange rates merely because the claims of the 1960s advocates (Milton Friedman, Harry Johnson) of smoothly operating outcomes under market arrangements turned out to be very wide of the mark almost everywhere. The case for or against activism or inactivism comes down to weighing the merits and faults of both. That is an empirical matter requiring clearly articulated alternatives. Merely to demonstrate human imperfection might provide catechisms for the faithful, but it is not sufficient to prove that activism has made the economic condition generally worse. It is a rough old economy out there.

\section{Reference}

Gruen, D. \& G. Shuetrim (1994), 'Internationalisation and the Macroeconomy', pp.309-63 in P. Lowe \& J. Dwyer (eds), International Integration of the Australian Economy, Reserve Bank of Australia, Sydney. 